\title{
O Poder Investigativo do Ministério Público na Seara Criminal e a PEC 37/2011
}

\author{
The Power of Criminal Investigation by the Prosecutor and PEC 37/2011
}

\section{CYNTHIA VERAS GODEIRO}

Graduada em Direito pela UFRN, Tecnóloga em Comércio Exterior pelo IFRN, Pós-Graduada em Direito do Estado pela Universidade Anhanguera-Uniderpi, Advogada.

Submissão: 18.04 .2013

Decisão Editorial: 28.05.2013

RESUMO: 0 presente estudo tem por objetivo analisar a compatibilidade entre as funções e a natureza do Ministério Público em relação à atividade da investigação criminal, conforme modelo processual penal brasileiro e perfil institucional que the foi delineado pela Constituição Federal de 1988. A metodologia aplicada consiste na pesquisa exploratória descritiva por meio de documentos oficiais, livros e artigos científicos. Discorre-se sobre a investigação criminal no Brasil, examinando o papel das polícias e os argumentos favoráveis e contrários à investigação criminal pelo Ministério Público à luz da Proposta de Emenda Constitucional n 37/2011. Por fim, defende-se que o Ministério Público, autorizado pela Constituição Federal, pode, quando haja fundamento para tanto, conduzir investigações criminais, ainda que sua atuação decorra de uma necessidade circunstancial e passível de efetivo controle jurisdicional.

PALAVRAS-CHAVE: Persecução criminal; Ministério Público; PEC 37/2011; Constituição Federal de 1988.

ABSTRACT: The present study aims to examine the compatibility between the functions and nature of the prosecutor in relation to the activity of a criminal investigation, according to the model of criminal procedure and Brazilian institutional profile that has been outlined by the Federal Constitution of 1988. The methodology applied in this work consists of descriptive exploratory research through official documents, book and scientific articles. Talks over the criminal investigation in Brazil, examining the role of the police and arguments for against criminal investigation by prosecutors in light of the Proposed Constitutional Amendment number $n^{0} 37 / 2011$. Finally, it's argued that prosecutors authorized by the Constitution, can, when there are grounds to do so, conduct criminal investigations, even though his performance arises from a need circumstantial and subject to effective judicial review.

KEYWORDS: Criminal investigation; PEC 37/2011; Prosecutors; Federal Constitucion of 1988. 
SUMÁRIO: Introdução; 1 A nova ordem constitucional e os modelos de investigação criminal no Brasil à luz do direito comparado; 2 A PEC 37/2011 e seu reflexo na atuação funcional do Ministério Público; 30 Ministério Público e a investigação criminal; 3.1 Da legitimidade constitucional e legal inerente à função investigatória exercida pelo Parquet; 3.2 Da inexistência de dispositivo constitucional conferindo o monopólio da persecução criminal à polícia judiciária; 3.3 Da precípua compatibilização entre a função investigatória e a promoção da ação penal; Conclusão; Referências.

\section{INTRODUÇÃ̃O}

Em meio ao desenvolvimento articulado das sociedades criminosas no País, os mecanismos de repressão ao crime se mostram cada vez mais insuficientes, de modo a gerar uma famigerada sensação de impunidade no seio social. Sendo assim, a crescente capacidade de organização e sofisticação das estruturas de atuação dos criminosos está desafiando decisivamente a efetividade da aplicação das leis penal e processual penal no Brasil, as quais têm por objetivo oferecer uma solução adequada às condutas desviantes que oferecem risco ao convívio e à paz social.

Nesse espectro, adveio a Constituição Federal de 1988 presenteando a nação com uma "nova" instituição de combate ao crime e às injustiças sociais: um Ministério Público voltado essencialmente à defesa dos interesses da coletividade, dotado de prerrogativas e instrumentos de atuação compatíveis à concretização da sua elevada missão conferida pela Carta Maior.

Entretanto, recente Proposta de Emenda Constitucional no 37, que tramita no Congresso Nacional, vem causando bastante polêmica no cenário jurídico brasileiro, na medida em que propõe o acréscimo do $\S 10$ ao art. 144 da $\mathrm{CF}$, visando a atribuir à polícia judiciária o monopólio do poder de investigação criminal no Brasil.

À luz da referida proposta, surgem as seguintes hipóteses a serem enfrentadas neste trabalho: a existência de previsão constitucional e legal para o exercício da atividade investigatória pelo Ministério Público na seara criminal; e se há dispositivo constitucional garantindo exclusividade aos órgãos que exercem função de polícia judiciária para a apuração de infrações constitucionais, bem como a possibilidade do Ministério Público aglutinar as funções investigatória e acusatória. Para tanto, far-se-ão necessárias breves considerações históricas sobre os modelos de investigação criminal no Brasil e no mundo; discussões acaloradas acerca da competência constitucional atribuída ao Ministério Público e à polícia judiciária para investigações criminais, tendo por referência os reflexos a serem causados com a eventual aplicação da Proposta de Emenda Constitucional nº 37/2011. 
Insta esclarecer que não se pretende esgotar todos os debates acerca da temática, nem tampouco congregar uma reflexão absoluta e unilateral sobre "como" e a "quem" compete o exercício da investigação criminal no País, isso porque a causa vai muito além de uma simples disputa política entre órgãos e instituições (Ministério Público e polícia judiciária), de forma que a questão será avaliada em compromisso com a realização dos postulados inerentes aos direitos fundamentais da pessoa humana e ao Estado Democrático de Direito.

\section{A NOVA ORDEM CONSTITUCIONAL E OS MODELOS DE INVESTIGAÇÃO CRIMINAL NO BRASIL À LUZ DO DIREITO COMPARADO}

No berço das civilizações antigas, encontra-se o surgimento dos modelos processuais penais adotados pelos Estados na contemporaneidade. Isso significa que o conhecimento das experiências vividas pelos povos antepassados mostra-se de suma importância para a compreensão e melhor interpretação dos sistemas acusatórios nos dias atuais.

Assim sendo, em tempos remotos, cumpre registrar que a persecução criminal era eminentemente privada. Pela autotutela, incumbiam-se ao particular a colheita de provas e a acusação penal, podendo-se, ainda, utilizar o mecanismo de autocomposição para solução dos conflitos no campo penal.

Entretanto, com a evolução das sociedades, o Estado passou a ser o único detentor do poder de punição (jus puniendi) e investigação na esfera penal, dando início a um sistema conhecido por inquisitorial ${ }^{1}$. Nos ensinamentos de Ada Pellegrini² ${ }^{2}$ o embrião do sistema inquisitório surgiu na sociedade egípcia ${ }^{3}$ e sofreu fortes influências do direito canônico, caracterizando-se pelo desenvolvimento de um processo "investigatório" sob o comando de um juiz investido de dupla função - investigar e sentenciar, comprometendo decisivamente a imparcialidade das decisões proferidas.

Em contrapartida, surge na Grécia antiga o modelo de acusação com contornos nitidamente acusatórios, havendo uma clara distinção entre os

1 Sobre o sistema, Paulo Rangel (Direito processual penal. 18. ed. Rio de Janeiro: Lumes Juris, 2011) afirma que, "portanto, o próprio órgão que investiga é o mesmo que pune. No sistema inquisitivo, não há separação de funções, pois o juiz inicia a ação, defende o réu e, ao mesmo tempo, julga-o. [...] No sistema inquisitivo, o juiz não forma seu convencimento diante das provas dos autos que Ihes foram trazidas pelas partes, mas visa convencer as partes de sua íntima convicção, pois já emitiu, previamente, um juízo de valor ao iniciar a ação".

2 Ada Pellegrini Grinover apud PRADO, Geraldo. Sistema acusatório - A conformidade constitucional das leis processuais penais. Rio de Janeiro: Lumen Juris, 2006. p. 71.

3 Acerca do sistema inquisitorial adotado no Egito, Bruno Freire Calabrich (2006, p. 22) acrescenta que a prática da persecução penal era de iniciativa oficial, na qual "o poder de julgar concentrava-se nas mãos dos sacerdotes, havendo um Tribunal Supremo incumbido de decidir sobre os crimes mais graves, e, nas províncias, juízes, auxiliados por delegados, encarregados dos julgamentos de infrações menores". 
"crimes públicos" e "crimes privados", sendo os primeiros julgados por um Tribunal Popular, após a acusação do ofendido e a defesa do acusado, oportunidade em que cada um deveria elaborar suas alegações e provas correspondentes.

Nesse esteio, a figura do juiz inquisidor, nascida na época do Império Romano e dotado de amplos poderes, foi veemente combatida pelos ideais iluministas e proscritas na Revolução Francesa ${ }^{4}$. Buscando conciliar a efetividade do método inquisitivo, sobretudo quanto à colheita de provas, com a necessidade de assegurar os direitos fundamentais dos indivíduos, o Código de Napoleão de 1808 adotou o sistema misto acusatório ${ }^{5}$ desenvolvido em três fases, "de la police judiciaire, de l'instruction et du jugement", no qual a ação penal pública se dava sempre por iniciativa do Ministério Público, cabendo ao ofendido a ação apenas para o ressarcimento de dano.

Ao longo dos séculos XIX e XX, observou-se que os países optaram por sistemas processuais penais de forma semelhante, alguns preferindo o sistema misto (inquisitivo/acusatório) e outros o sistema acusatório. Nessa perspectiva, pode-se inferir que, embora alguns países europeus adotem o modelo de juizado de instrução, no qual as funções de acusação, investigação e instrução são bastante delineadas, sofrendo uma separação bastante rígida, a participação ativa e direta do Ministério Público na investigação criminal é uma tendência mundial e enraizada nos mais diversos ordenamentos jurídicos modernos.

Oportuno destacar, portanto, a relação entre o Ministério Público e a polícia em alguns países da Europa continental no que diz respeito à atuação em investigações criminais. No modelo francês, o atual Código Penal do país estabelece que a polícia judiciária, com o advento da infração penal, fica encarregada de encontrar a autoria e materialidade do crime, porém, realizando tais atividades sempre sob orientação do Ministério Público. Na mesma linha, os Códigos Penais da Itália e Espanha consagram o princípio da obrigatoriedade da ação penal pública na sua legislação, cabendo ao Ministério Público conduzir as investigações preliminares, auxiliado pela polícia judiciária que lhe está subordinada ${ }^{6}$.

4 AMADO, Verônica Lazar. A investigação criminal pelo Ministério Público. Aracaju: Gráfica Textopronto, 2002. p. 44.

5 Aprofundando o tema, Paulo Rangel (2011, p. 92) infere: "O sistema misto tem fortes influências do sistema acusatório privado de Roma e do posterior sistema inquisitivo desenvolvido a partir do Direito canônico e da formação dos Estados nacionais sob o regime da monarquia absolutista. Procurou-se com ele temperar a impunidade que estava reinando no sistema acusatório, em que nem sempre o cidadão levava ao conhecimento do Estado a prática da infração penal, fosse por desinteresse ou por falta de estrutura mínima e necessária para suportar as despesas inerentes àquela atividade; ou, quando levava, em alguns casos, fazia-o movido por um espírito de mera vingança".

6 AMADO, Verônica Lazar. Op. cit., p. 44 
Ainda com base no direito comparado, o modelo alemão institui que:

Cumpre ao Ministério Público a direção e fiscalização da polícia judiciária. Em casos de maior relevância, o Ministério Público não só orienta, mas assume pessoalmente a condução das investigações. Tal é o poder de mando sobre os agentes da polícia que as ordens emanadas do Ministério Público sobrepõem-se à de seus superiores hierárquicos. ${ }^{7}$

Note-se que a expressividade conferida ao Parquet em âmbito mundial é tão evidente que, em Portugal, a polícia judiciária foi criada como órgão auxiliar do Ministério Público, ficando a cargo deste a instrução preparatória destinada a reunir elementos probatórios necessários à acusação. Por este sistema, as diversas autoridades (peritos, médicos, policiais) atuam como agentes colaboradores ao trabalho principal desenvolvido pelo representante do órgão ministerial.

Ademais, em outros países, inclusive na América Latina, a intervenção direta do Ministério Público nas investigações criminais é cada vez mais assente, sobretudo nos casos que envolvem o controle da atividade policial, com vistas a evitar prisões arbitrárias e garantir o exercício pleno das liberdades públicas.

No Brasil, o modelo de Juizado de Instrução teve pouca aderência, tendo em vista que, assim como os países supramencionados, defende-se que a legitimidade das diligências investigatórias do Ministério Público decorre de nova ordem constitucional, de modo que não se pode vislumbrar uma distância colossal entre o Ministério Público e a polícia judiciária no exercício de suas respectivas atribuições, os quais têm, por finalidade: defesa da ordem jurídica democrática e preservação da ordem pública, respectivamente. Portanto, entende-se que tais finalidades decorrem de um interesse comum e convergem para uma finalidade maior que é a pacificação social $^{8}$.

Não obstante a Constituição Federal de 1988 tenha fixado os parâmetros para o melhor desempenho do sistema acusatório (com forte tendência garantista) no Brasil, bem como dotado o Ministério Público de prerrogativas funcionais e mecanismos de atuação necessários ao combate efetivo ao crime, alguns juristas ainda sustentam equivocadamente que a Carta Maior deve ser interpretada restritivamente para amoldar-se ao obsoleto Código de Processo Penal de 1941.

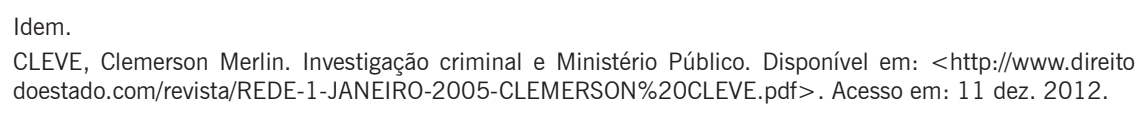


Em verdade, embora a questão sobre o modelo processual penal adotado pelo Brasil ainda seja divergente na doutrina, notadamente pelos resquícios advindos do modelo inquisitório na fase da investigação policial, na qual inexistem garantias processuais como o contraditório e a ampla defesa, a investigação preliminar, no padrão brasileiro, não vincula o entendimento do Magistrado, podendo a fase processual ser refeita com a devida garantia de todos os princípios fundamentadores do sistema acusatório, não subsistindo a ideia de que o sistema processual penal brasileiro é misto, tampouco inquisitório. Corrobora com tal entendimento o jurista Paulo Rangel ${ }^{9}$ :

Hodiernamente, no Direito pátrio, vige o sistema acusatório (cf. art. 129, I, da (RFB), pois a função de acusar foi entregue, privativamente, a um órgão distinto: o Ministério Público, e, em casos excepcionais, ao particular. Não temos a figura do juiz instrutor, pois a fase preliminar e informativa que temos antes da propositura da ação penal é a do inquérito policial e este é presidido pela autoridade policial. Durante o inquérito policial, como vamos ver mais adiante (cf. item 2.3 infra), o sigilo e a inquisitividade imperam, porém, uma vez instaurada a ação penal, o processo torna-se público, contraditório, e são asseguradas aos acusados todas as garantias constitucionais.

Ocorre que a constante necessidade de adaptação do direito às novas realidades sociais não pode servir de justificativa para decisões políticas que, em dado momento histórico, destinam-se a proteger interesses particulares em detrimento dos direitos coletivos. Sendo assim, deve-se analisar criticamente todo e qualquer projeto de emenda à Constituição, principalmente a "recente" proposta de no 37/2011, atualmente em trâmite no Congresso Nacional, tendente a modificar o sistema investigatório criminal do nosso País, sob pena de restar comprometido o próprio Estado Democrático de Direito, conforme se delineará a seguir.

\section{A PEC 37/2011 E SEU REFLEXO NA ATUAÇÃO FUNCIONAL DO MINISTÉRIO PÚBLICO}

Corolário breve panorama histórico-evolutivo sobre os modelos de investigação criminal, reprise-se que o Brasil é um dos poucos países que ainda mantém um sistema obsoleto de investigação preliminar policial sem o controle efetivo do Ministério Público. Embora o modelo atual seja fortemente rechaçado, de modo geral, pelos membros do Ministério Público e do Judiciário, tendo sido considerado como um verdadeiro entrave ao combate à impunidade e concretização da justiça, eis que surge no cenário político brasileiro a Proposta de Emenda à Constituição no 37/2011, em trâmite no Congresso Nacional e de autoria do Deputado Federal Lourival Mendes.

9 RANGEL, Paulo. Op. cit., p. 91. 
Referida emenda propõe o acréscimo do $\S 10$ ao art. 144 da Constituição Federal, com a seguinte redação: "Art. 144. [...] § 10. A apuração das infrações penais que tratam os $\S \S 1^{\circ}$ e $4^{\circ}$ deste artigo, incumbem privativamente às polícias federal e civil dos Estados e do Distrito Federal respectivamente". Em síntese, a justificação ${ }^{10}$ ofertada pelo autor da proposta consiste em afirmar que "as demais competências ou atribuições de outros segmentos para a investigação criminal, definidas em nossa Constituição Federal não serão afetadas", como no caso das Comissões Parlamentares de Inquérito, por força do "princípio que não há revogação tácita de dispositivos constitucionais, cuja interpretação deve ser conforme".

No mérito, defende ainda que a falta de "regras claras definindo a atuação dos órgãos de segurança pública neste processo têm causado grandes problemas ao processo jurídico no Brasil". Desse modo, "por intermédio exclusivo da polícia civil e federal propiciará às partes - Ministério Público e a defesa, além da indeclinável robustez probatória servível à propositura e exercício da ação penal, também os elementos necessários à defesa [...]". Inegavelmente, o Deputado Federal Lourival Mendes pretende conferir exclusividade $^{11}$ ao exercício das investigações criminais à Polícia Judiciária, de forma que qualquer participação dos não legitimados pela Constituição no inquérito, inclusive o Ministério Público ou demais instituições, assim como Órgãos Públicos que colaboram com a atividade de investigação, gerarão provas ilícitas e, portanto, inadmissíveis no processo $^{12}$.

Nesse ínterim, defensores da PEC 37/2011, denominada por estes como "PEC da Legalidade", acreditam que a proposta apenas reafirma o que já reza a Constituição da República, delimitando os papéis de cada um dos agentes públicos que participam da atividade persecutória penal do Estado. De fato, um dos reflexos da emenda, caso aprovada, será a rígida separação das funções de "investigar" em relação às demais ("acusar" e "julgar"), de modo que o Ministério Público não poderá exercer qualquer atividade relacionada à investigação na seara criminal. Contudo, será que a ausência de flexibilização no modelo investigatório e falta de cooperação entre as instituições será a melhor alternativa para a defesa da sociedade contra a crescente criminalidade?

10 Inteiro teor da Proposta de Emenda Constitucional $n^{\circ} 37 / 2011$ poderá ser consulta por meio do link: <http://www.camara.gov.br/proposicoesWeb/prop_mostrarintegra;jsessionid=4B2C20AC2CE43FC290B D7AEF669C8E9C.node2?codteor=969478\&filename=Tramitacao-PEC+37/2011 > .

11 O Supremo Tribunal Federal decidiu de forma reiterada e unânime que a expressão "privativa" conferida pela Constituição à atuação do Ministério Público na ação penal pública é sinônima de "exclusivo" ou "monopólio". Alguns julgados: RE 296185/RS, Órgão Julgador: 2a Turma; HC 101369/SP, Rel. Min. Dias Toffoli, Órgão Julgador: $1^{\text {a }}$ Turma.

12 Dispõe art. 5, LVI, da Constituição Federal: "São inadmissíveis, no processo, as provas obtidas por meios ilícitos". 
O Presidente da Associação de Delegados de Polícia do Brasil, Paulo D'Almeida ${ }^{13}$, é bastante taxativo ao afirmar que, no Brasil, o Ministério Público é a instituição que acusa, sendo incompatível, portanto, com sua função institucional, a atividade de investigar, sob pena de restar comprometido o equilíbrio entre acusação e defesa, caso toda prova seja produzida pela investigação. Ao ensejo, acrescentou ainda que:

Polícia judiciária investiga, promotor acusa, advogado defende e juiz julga. Quebrar essa sistemática fere mortalmente a segurança jurídica do cidadão. Investigação realizada pelo Ministério Público fere direitos individuais. Isso, sim, é contrário aos interesses da sociedade. [...]

Cooperação e integração não são sinônimos de invasão de competência. O que gera insegurança jurídica é o órgão responsável por ser o fiscal da lei querer agir à margem da lei, invadindo a competência das Polícias Judiciárias. E quem fiscaliza o fiscal?

Não obstante os simpatizantes da PEC 37 argumentarem no sentido de que permanecerá intocado o controle externo da atividade policial pelo Ministério Público, torna-se cada vez mais evidente que se as diligências requeridas pelo Parquet à autoridade policial não forem realizadas a contento, sejam por fatores de corrupção ou tratar-se de crimes envolvendo policiais e investigados com demasiado poder político e econômico, não restará outra solução ao membro ministerial senão o arquivamento do inquérito policial, aumentando significativamente a impunidade ${ }^{14}$.

Em outro pórtico, outro provável impacto relacionado à referida proposta de emenda no Direito brasileiro será a anulação de todas as ações penais que tiveram suas investigações penais promovidas direta ou indiretamente pelos membros do Ministério Público em qualquer instância do Poder Judiciário, inclusive naquelas investigações realizadas pelo Gaecos (Grupos de Combate ao Crime Organizado), por força do princípio da irretroatividade da lei penal, com previsão no art. 5ํ, LVI'

Oportuno ressaltar que a questão da investigação direta pelo Ministério Público ainda será enfrentada pelo Pleno do Supremo Tribunal Federal, ainda que a $2^{\text {a }}$ Turma e alguns Ministros ${ }^{16}$ já tenham sinalizado que o

13 Matéria da Adepol do Brasil, publicada no Jornal O Estadão de S. Paulo, no dia 15 de janeiro de 2013, denominada "A hora da verdade", defendendo a PEC 37/2011. Disponível em: < http://www.adepoldobrasil. com.br/2.0/presidente-da-associacao-de-delegados-de-policia-do-brasil-paulo-dalmeida-o-estado-de-spaulo/>. Acesso em: 10 fev. 2013.

14 LACERDA, Alexandre M. B. Considerações sobre a PEC 37/2011 e seus reflexos na investigação criminal no Brasil. Disponível em: <http://www.conamp.org.br/Lists/artigos/DispForm.aspx?ID=194>. Acesso em: 9 fev. 2013.

15 Art. 5, inciso LVI, da Constituição Federal preceitua: "A lei penal não retroagirá, salvo para beneficiar o réu".

16 No Recurso Extraordinário n 468.523, votaram nesse sentido os Ministros: Ellen Gracie, Eros Graus, Joaquim Barbosa e Cezar Peluzo. 
entendimento definitivo da Corte Suprema deverá ser no sentido do reconhecimento da competência do Ministério Público para investigar crimes, sobretudo nos casos em que haja envolvimento de policiais.

Por último, cabe alertar que com a aprovação da Proposta de Emenda Constitucional no 37 ocorrerá uma mudança substancial no sistema acusatório do nosso País, interferindo no funcionamento e atuação de todos os Poderes, órgãos e instituições com atribuições investigativas, de forma a aumentar drasticamente a demanda de persecuções criminais sob a responsabilidade policial, a qual, atualmente, não dispõe de infraestrutura e independência funcional necessária ao exercício pleno de seu mister.

\section{MINISTÉRIO PÚBLICO E A INVESTIGAÇÃO CRIMINAL}

\subsection{Da legitimidade constitucional e legal inerente à Função Investigatória eXercida Pelo Parquet}

Dada a constante mutação social atrelada à evolução do direito, a nova ordem constitucional conferiu ao Ministério Público poderes e prerrogativas funcionais capazes de promover a defesa da ordem jurídica, do regime democrático e dos interesses sociais e individuais indisponíveis, conferindo-Ihe o status de instituição permanente e essencial à função jurisdicional do Estado ${ }^{17}$.

Acerca dessa elevada missão conferida ao Parquet, Hugo Nigro Mazzilli ${ }^{18}$ afirma que o Constituinte de 1988, reconhecendo a abertura democrática que vivemos, supunha um Ministério Público forte e independente, que pudesse efetivamente defender as liberdades públicas, os interesses difusos e coletivos, o meio ambiente, o patrimônio público, as vítimas não só da violência como as da chamada criminalidade do colarinho branco, de modo a revelar-se como um dos legítimos guardiões do próprio regime democrático.

Nesse esteio, extrai-se do Texto Constitucional uma série de atribuições, como instrumentos indispensáveis à concretização de sua função institucional, tais como: "a promoção privativa da ação penal e o exercício do controle externo da atividade policial" (art. 129, incisos III e VII); "expedir notificações nos procedimentos administrativos de sua competência, requisitando informações e documentos para instruí-los, e requisitar diligências

17 Art. 127, caput, da Constituição Federal.

18 MAZZILLI, Hugo Nigro. Op. cit., p. 74. 
investigatórias e a instauração do inquérito policial" (art. 129, incisos VI e VIII).

De tais dispositivos, exsurge cristalina a intenção do legislador constitucional em conferir plena autonomia ao Ministério Público no desempenho da atividade de coletar elementos necessários à sua convicção (opinio delicti) para oferecimento da denúncia, fim último do inquérito policial. No mesmo sentido, dispõe o art. 57 do Código de Processo Penal, com destaque aos versos finais acerca da investigação direta:

Se o Ministério Público julgar necessários maiores esclarecimentos e documentos complementares ou novos elementos de convicção, deverá requisitá-los, diretamente, a quaisquer autoridades ou funcionários que devam ou possam fornecê-los.

Destaca-se, ainda, o teor do inciso IX, art. 129, da Carta Maior, o qual institui expressamente competir ao Ministério Público "exercer outras funções que the forem conferidas, desde que compatíveis com sua finalidade [...]". Dessa forma, mostra-se com uma verdadeira "armadilha argumentativa", proferida por aqueles que desafiam a legitimidade do Ministério Público em promover diligências investigatórias na seara criminal, a visão de que tal possibilidade não se encontraria expressa na Constituição, sendo o rol de atribuições dotado de taxatividade, haja vista que a norma em apreço qualifica-se como uma cláusula de abertura - legalmente concretizável - ao exercício, pelo Ministério Público, "de outras funções" compatíveis com sua finalidade institucional ${ }^{19}$.

Atrelado à questão de compatibilidade a nível constitucional, apresenta-se o aspecto legal conferido ao Parquet para investigar em âmbito criminal. Veja-se que a Lei Complementar no 75/93 concretiza as disposições constitucionais, reafirmando que: "Art. 5음o funções institucionais do Ministério Público da União: [...] VI - Exercer outras funções previstas na Constituição Federal e na lei". Além disso, prevê, em seu art. $8^{\circ}$, em seus diversos incisos, as atribuições de "realizar inspeções e diligências investigatórias", "expedir notificações e intimações" e "requisitar informações, exames, perícias e documentos".

Nos ensinamentos de Lenio Streck ${ }^{20}$, resulta nítida a relação meio-fim advinda do cotejo dos dispositivos legais e constitucionais retromencionados, de forma que a função de investigar está legitimamente embutida no

19 STRECK, Lenio L.; FELDENS, Luciano. Crime e constituição: a legitimidade da função investigatória do Ministério Público. Rio de Janeiro: Forense, 2003. p. 77-78.

20 Idem. 
texto jurídico "realizar diligências investigatórias", conforme interpretação baseada na tradição jurídico-linguística.

Outrossim, diversos outros diplomas legais, como: a Lei de Ação Civil Pública - LACP (arts. 8o a 10), a Lei Orgânica Nacional do Ministério Público - LONMP (art. 26, I), a Lei Orgânica do Ministério Público da União - LOMPU (arts. 7ํㅡㄹ I, e $8^{\circ}$ ), o Estatuto da Criança e do Adolescente (art. 201, VI e VI), o Estatuto do Idoso (art. 74, VI, da Lei no 10.741/2003) - instrumentalizam a atividade investigatória direta por parte do Ministério Público, não tendo importância se os fatos a serem apurados ensejem responsabilidades nas áreas civis ou penais.

Tomando por base todo o acervo normativo apresentado em relação à atividade ministerial, torna-se superada, neste primeiro momento, a partir de uma leitura simples e interpretação sistemática do Texto Constitucional, a questão da legitimidade atribuída ao Ministério Público para investigações cíveis e criminais, sobretudo por tratar-se de uma instituição destinada à defesa dos interesses indisponíveis da sociedade.

\subsection{Da INEXISTÊNCIA DE DISPOSITIVO CONSTITUCIONAL CONFERINDO 0 MONOPÓLIO DA PERSECUÇÃO CRIMINAL À POLÍCIA JUDICIÍRIA}

Um segundo argumento utilizado pelos defensores da PEC 37/2011, no intuito de justificar a necessidade de aplicação do Projeto à Constituição, tem sido a dicção expressa do art. 144, §§ $1^{\circ}$, I e IV, e $4^{\circ}$ da Constituição Federal ${ }^{21}$, o qual supostamente estabelece que atribuição da apuração das infrações criminais seja exclusiva da polícia judiciária. Portanto, por essa ótica, a referida proposta de emenda estaria apenas reconhecendo à função policial algo que já Ihe foi conferido (poder investigativo) pelo próprio Texto Constitucional.

Porém, tal interpretação revela-se totalmente equivocada e não merece prosperar, tendo em vista que o dispositivo atacado foi enfático em garantir exclusividade à Polícia Federal no desempenho das atividades de competência da Polícia Judiciária da União, de modo a excluir a atuação de outras polícias civisis $^{22}$, e não com relação à investigação de crimes, não se podendo concluir pela Constituição a previsão de qualquer monopólio

210 art. 144, I e IV, da CF, dizem que cabe à polícia federal "apurar infrações penais contra a ordem política e social ou em detrimento de bens, serviços e interesses da União ou de suas entidades autárquicas e empresas públicas, assim como em outras infrações cuja prática tenha repercussão interestadual ou internacional e exija repressão uniforme, segundo se dispuser em lei"; e, "exercer, com exclusividade, a polícia judiciária da União".

22 Art. 144, $\S 4^{\circ}$, da CF: "As polícias civis, dirigidas por delegados de polícia de carreira, incumbem, ressalvada a competência da União, as funções de polícia judiciária e a apuração de infrações penais, exceto as militares". 
referente a essa atividade. Assim confirma Clemerson Merlin Cleve ${ }^{23}$ no seu estudo sobre o tema:

Levando a cabo a interpretação do dispositivo em questão, resta assentado que à Polícia Federal é reservada, com exclusividade, a função de polícia judiciária da União, ou seja, não há exclusividade quanto a apuração de crimes e a exclusividade referida se opera em relação ao âmbito de atuação das funções de polícia judiciária federal, em contrapartida ao das polícias civis. Assim, não há exclusividade constitucionalmente garantida aos órgãos que exercem função de polícia judiciária para a apuração de infrações criminais.

Além disso, no nosso sistema processual penal, em decorrência do processo de consolidação do Estado Democrático de Direito e das garantias constitucionais, não há uma delimitação rígida sobre a função de apuração de infrações criminais, de modo que a persecução penal deve ser considerada como típica e não exclusiva da polícia judiciária, não impedindo o Ministério Público de realizar a investigação e acusação em determinado caso, ainda que excepcionalmente, sem esvaziar a esfera funcional da instituição policial, não caracterizando, portanto, a usurpação de competência entre os órgãos.

Nessa feita, infere-se, seguramente, que a Constituição Federal não conferiu à polícia judiciária a exclusividade das investigações criminais, e sim do inquérito policial. Contudo, este não se apresenta como o único procedimento dirigido à apuração de infrações penais. Nessa esteira foi o julgado da ilustre Ministra do Superior Tribunal de Justiça Laurita Vaz no voto referente ao Recurso Ordinário em HC no 12.871/SP, de sua relatoria (13 de abril de 2004):

Verifica-se, pois, que a legitimidade do Ministério Público para conduzir diligências investigatórias decorre de expressa previsão constitucional, oportunamente regulamentada pela Lei Complementar, mesmo porque proceder a colheita de elementos de convicção, a fim de elucidar a materialidade do crime e os indícios de autoria, e um consectário lógico da própria função do órgão ministerial de promover, com exclusividade, a ação penal pública. Ademais, dispensável dizer que a polícia judiciária não possui o monopólio da investigação criminal. De fato, o próprio Código de Processo Penal e claro ao dizer, no parágrafo único do seu art. $4^{\circ}$, que a competência da polícia judiciária não exclui a de outras autoridades administrativas. Exemplos disso são as investigações efetuadas pelas Comissões Parlamentares de Inquérito; o inquérito judicial presidido pelo juiz de direito da vara falimentar; o inquérito em caso de infração penal cometida na sede ou dependência do Supremo Tribunal Federal (RISTF, art. 43), entre inúmeros outros. Por fim, cumpre ressaltar que, como se sabe, a atuação do Parquet não está adstrita à existência do inquérito policial, podendo este ser dispensado,

23 CLEVE, Clemerson Merlin. Investigacão criminal e Ministério Público. Disponível em: <http://www.direito doestado.com/revista/REDE-1-JANEIRO-2005-CLEMERSON\%20CLEVE.pdf>. Acesso em: 11 dez. 2012. 
na hipótese de já existirem elementos suficientes para embasar a propositura da ação penal.

Com efeito, além do inquérito policial que é típico da polícia judiciária, a investigação criminal, consoante voto da Ministra Laurita Vaz, poderá ocorrer por meio de diversos procedimentos alheios à atividade policial, ou seja, por meio de procedimentos promovidos por órgãos do executivo, legislativo e judiciário, como nos seguintes casos: a) as comissões parlamentares de inquérito; b) inquéritos policiais militares, que não são conduzidos pela polícia civil, mas também se investigam crimes (na ADIn 1.494-MC, o STF admitiu a validade desses procedimentos); c) nas atividades de correição judicial (pode o Magistrado investigar crimes para fins correcionais); d) em matéria de crimes eleitorais, por abuso de poder econômico, as investigações pré-processuais são conduzidas pelo Corregedor-Geral Eleitoral (cf. art. 19 da LC 64/1990, cf. Inq. 593-2-MG/STF); e) nos processos administrativos, quem investiga é a autoridade administrativa processante; f) nos processos cíveis em geral, o juiz apura ilícitos civis que, não raro, são também ilícitos penais, o que enseja a comunicação direta dos fatos ao Ministério Público (CPP, art. 40); g) nos processos que correm nos Tribunais de Contas, esses órgãos podem apurar ilícitos penais, que serão comunicados diretamente ao Ministério Público; h) nos inquéritos civis conduzidos pelo Ministério Público, não raro se apuram fatos com conotação penal (LACP, arts. $8^{\circ}$ e $9^{\circ}$, e CF, art. 129, III) ${ }^{24}$.

Não se pretende advogar que a presidência do inquérito policial e todas as investigações criminais devem ser realizadas pelo Ministério Público ou com a interferência deste, na medida em que se reconhece que tais atividades são primordiais à polícia, como regra e não exceção. Entretanto, tal ponderação só reforça o entendimento que não há exclusividade constitucionalmente conferida a nenhum órgão ou instituição quanto à matéria de persecução criminal.

Ainda que assim não fosse, conferir o monopólio das investigações criminais à polícia judiciária, como pretende a Proposta de Emenda Constitucional no 37/2011, além de não encontrar legitimidade constitucional, conforme já demonstrado, constituir-se-ia como um verdadeiro atentado à moralidade e ao controle externo policial realizado pelo Ministério Público, haja vista que o inquérito policial teria um fim em si mesmo.

24 MAZZILI, Hugo Nigro. As investigações do Ministério Público para fins penais. Revista APMP em Reflexão, São Paulo: APMP, a. 1, n. 4, p. 12, 2005. 
Sobre esse assunto, em nível internacional, a Organização das Nações Unidas $(\mathrm{ONU})^{25}$ já demonstrou explicitamente sua desaprovação em relação à proposta de emenda em questão, recomendando justamente o contrário do que se pretende pela Comissão de Constituição e Justiça (CCJ) da Câmara: que o Ministério Público "conduza investigações independentes onde a polícia esteja envolvida em um assassinato, e que o direito do MP para conduzir suas próprias investigações seja melhor definido e afirmado".

O Relator recomenda inclusive que, em São Paulo, seja aprovada uma proposta para ampliar o Grupo de Atuação Especial de Controle Externo da Atividade Policial (GECEP) do MP, que atuaria na fiscalização de crimes e abusos cometidos pela polícia ${ }^{26}$.

Sendo assim, com base na análise de organismos internacionais atentos à realidade brasileira, conclui-se que a solução para o combate ao crime e à impunidade no Brasil não está necessariamente em monopolizar a atividade investigatória, e sim regulamentar o exercício dessa atividade com base em um juízo de cooperação entre as instituições, sem que, para isso, seja necessário coibir o efetivo desempenho obtido pelo Ministério Público nas persecuções criminais.

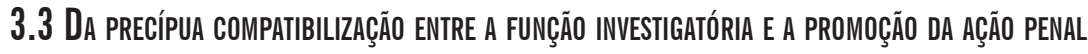

Uma vez demonstrada, em linhas pretéritas, a insubsistência dos argumentos acerca da suposta ilegitimidade constitucional e legal do poder investigativo desempenhado pelo Ministério Público em âmbito criminal, bem como a inexistência normativa conferindo o monopólio da atividade investigativa à polícia judiciária, cabe demonstrar ainda que não há qualquer incompatibilidade entre a referida função investigatória desempenha-

25 Relatório do Comissário da ONU Philip Alston, sobre Execuções Extrajudiciais, Sumárias ou Arbitrárias no Brasil. Trecho original: "During his mission the Special Rapporteur observed that the Public Prosecutor's Office is a widely respected institution and that, where progress had been made against police impunity, prosecutors had often played a key role. However, their role in investigations, particularly important with respect to police killings, was impeded in practice because the Civil Police often did not notify prosecutors of crimes until after 30 days, and because of challenges to prosecutors legal power to conduct investigations. The Special Rapporteur recommended that the Civil Police consult with prosecutors from the start of a homicide investigation, that prosecutors conduct independent inquiries where police were implicated in a killing, and that the right of prosecutors to conduct their own investigations should be clarified and affirmed". Texto na íntegra disponível em: <http://global.org.br/wp-content/uploads/2010/06/Relatório_de_ Seguimento_ONU_Alston2010_inglês.pdf> Acesso em: 28 mar. 2013.

26 Recomendação da ONU - A/HRC/14/24/Add.4, texto original: "In São Paulo, the State Prosecutor's office has a Special Action Group of External Control of Police Activities (GECEP), which has a mandate for police oversight, but cannot currently cover police intentional killings, or any abuses by the military police. The Special Rapporteur was informed that the Attorney-General for São Paulo has proposed that the GECEP be given the authority to investigate police killings, including 'resistance killings' in the greater São Paulo region". Disponível em: < http://global.org.br/wp-content/uploads/2010/06/Relatório_de_Seguimento_ONU_ Alston2010_inglês.pdf>. Acesso em: 28 mar. 2013. 
da pelo Parquet com o posterior oferecimento da ação penal em um mesmo processo.

Isso porque a própria Constituição de 1988, atribuindo exclusividade da ação penal pública ao Ministério Público, fez com que a atividade investigatória da polícia fosse revestida de um caráter puramente instrumental, em se tratando de crimes de ação pública, cuja finalidade é apenas a apuração da materialidade e autoria dos crimes com vistas a servir de base à atuação do titular da ação penal pública ${ }^{27}$.

Nesse contexto, caso seja aprovada a PEC 37/2011, o inquérito policial, atualmente considerado como instrumento dispensável ao desempenho da atividade-fim (promoção da ação penal pública), tornar-se-ia imprescindível na investigação criminal, fazendo com que apenas informações monopolizadas pela polícia fossem levadas ao conhecimento do judiciário, comprometendo seriamente a atuação do único titular da ação penal - o Ministério Público, quanto à sua faculdade de colher os elementos necessários a embasar sua pretensão, deparando-se eventualmente na contingência de promover ações e arquivamentos temerários.

Dessa forma, resta evidente a inviabilidade do monopólio policial nas persecuções penais, em virtude da estrutura organizacional precária da polícia, sobretudo em âmbito civil, e sua vinculação hierárquica ao órgão do Poder Executivo, sem dispor de qualquer prerrogativa institucional hábil a garantir a necessária independência no exercício da sua função. Atualmente, polícia judiciária vê-se cada vez mais impossibilitada de desempenhar sua atividade desvinculada da política, isto é, sem se importar totalmente com o grau de influência política e financeira do investigado.

E ainda, contrária à finalidade pretensiosa da proposta de emenda, insta advertir que o Ministério Público goza de poderes implícitos ${ }^{28}$ para realizar investigações criminais, enquanto parte legítima para a propositura da ação penal pública, haja vista que qualquer norma constitucional que atribui a um órgão a realização de um dado fim, implicitamente lhe permite o uso dos meios necessários e hábeis a atingir tal desiderato, salvo proibição expressa da própria Constituição.

27 Art. 12 do Código de Processo Penal: "O inquérito policial acompanhará a denúncia ou queixa, sempre que servir de base a uma ou outra".

28 Teoria dos poderes implícitos ("Theory implied and inherent powers") construída pela Corte Norte-Americana, com base no argumento do caso "Mac Culloch x Maryland", em 1819. Poderes implícitos são todos os poderes indispensáveis ao exercício de uma competência expressa: "Um governo, investido de tão amplos poderes, de cujo oportuno desempenho a felicidade e a prosperidade da nação dependem vitalmente, deve também ser investido de amplos poderes para seu desempenho" (Marshall apud CALABRICH, Bruno F. de C. A investigação criminal pelo Ministério Público: fundamentos e limites constitucionais. Dissertação de Mestrado pela Faculdade Direito de Vitória. Vitória/ES, 2006. Disponível em: <http://www.fdv.br/mestrado / dissertacoes/Bruno\%20Freire\%20de\%20Carvalho\%20Calabrich.pdf>. Acesso em: 15 mar. 2013 p. 7). 
Pela Teoria dos Poderes Implícitos, após exuberante síntese no voto do Ministro Celso de Mello ${ }^{29}$, aduz-se que, ao passo que a Constituição atribui a um órgão determinado encargo, implicitamente lhe confere também os meios para sua realização. Nesse caso, a investigação criminal afigura-se como um poder implícito ao promotor de justiça na sua árdua função de coletar elementos suficientes ao seu convencimento motivado acerca da autoria e materialidade criminosa, conforme exposto exaustivamente.

Em outra vertente, o desempenho das investigações criminais promovidas pelo Ministério Público não deve ser considerado parcial e tendencioso a coligir provas a uma futura condenação, como fazem acreditar alguns debatedores da PEC 37/2011, haja vista que sua função não está atrelada necessariamente a um propósito cruelmente condenatório e punitivo. $\mathrm{Na}$ verdade, sua missão é de velar, utilizando de todos os meios possíveis, pela correta aplicação da lei, tanto processual como material, que no processo resume-se na obtenção de uma sentença legal e justa ${ }^{30}$.

Na prática, tem sido indispensável e fundamental ao combate à impunidade a atuação ministerial na seara criminal, ainda que tais diligências não devam legitimar-se como regra geral, mas sim no "plano da necessidade circunstancial"31 em casos de omissão policial ou insuficiência de informações coletadas por esta autoridade para formulação da denúncia ministerial.

Entretanto, isto não significa que o Ministério Público, caso venha a exceder-se no exercício de suas funções, esteja acima da lei ou de qualquer suspeita na sociedade brasileira. Pelo contrário, em casos de abuso de poder ou sempre que houver lesão ou grave ameaça a direito, o representante do Parquet poderá ser considerado como autoridade coatora para fins de utilização dos "remédios constitucionais", tais como habeas corpus e mandado de segurança.

Acrescente-se que, além dessas garantias, por meio da Emenda Constitucional no 45/2004, foi criado o Conselho Nacional do Ministério Público, responsável pela realização do Controle Externo da Instituição (art. 130-A

29 Ministro Celso de Mello afirma na Ação Direta de Inconstitucionalidade n 2.797-2-Distrito Federal: "Esta Suprema Corte, ao exercer o seu poder de indagação constitucional, deve ter presente sempre essa técnica lógico-racional, fundada na teoria dos poderes implícitos [...]. Não constitui demasia, neste ponto, a lição definitiva de Rui Barbosa, cuja precisa abordagem dos poderes implícitos assinala: '[...] Essa verdade fundada pelo bom senso é de que - em se querendo os fins, se hão de querer, necessariamente, os meios; a de que se conferirmos a uma autoridade uma função, implicitamente the conferimos os meios eficazes para exercer essas funções [...]'. Quer dizer que, uma vez conferida uma atribuição, nela se consideram envolvidos todos os meios necessários para sua execução regular. Este o princípio; esta, a regra".

30 CARNEIRO, Paulo Cezar Pinheiro. Op. cit., p. 9.

31 STRECK, Lenio Luiz, FELDENS, Luciano. Op. cit., p. 105. 
da Constituição Federal), à semelhança do Conselho Nacional de Justiça (CNJ) voltado ao controle efetivo das ações do Poder Judiciário.

Sábias palavras foram proferidas pelo Ministro Carlos Ayres Britto ${ }^{32}$, no julgamento do Inquérito $\mathrm{n}^{\circ}$ 1.968-2/DF: "pela possibilidade de abuso, não podemos coibir o uso", máxime diante dos incontáveis resultados positivos que resultaram da atuação do Ministério Público no âmbito da investigação criminal ${ }^{33}$. Vale a pena relembrar, inclusive, o célebre caso ocorrido há algumas décadas em São Paulo, na apuração dos crimes do "esquadrão da morte" quando houve a corajosa e persistente atuação ministerial, com diligências diretas promovidas sob direção do Procurador de Justiça Hélio Bicudo ${ }^{34}$.

Em outra dimensão, recentemente, foi divulgada a "Carta de Brasília"35, assinada pelas seguintes instituições: Procuradoria-Geral da República (PGR); Movimento do Ministério Público Democrático (MPD); Magistrados Europeus pela Democracia e Liberdades (Medel); Federação de Associações de Juízes para a Democracia da América Latina e Caribe; Colégio de Escolas Superiores do Ministério Público (CDEMP); Colégio Nacional de Ouvidores dos Ministérios Públicos; Colégio Nacional de Procuradores Gerais (CNPG); Associação Nacional dos Membros do Ministério Público (Conamp); Associação Nacional de Procuradores da República (ANPR); Associação Paulista do Ministério Público (APMP); Ministério Público do Estado de São Paulo (MP/SP); e Escola Superior do Ministério Público de São Paulo (ESMPSP), relembrando que:

[...] o Brasil assinou o Estatuto de Roma que, por sua vez, criou o Tribunal Penal Internacional, optando, no plano internacional, por um modelo de Ministério Público investigativo. Ao vedar o poder investigatório, seriam desrespeitados princí-

32 Ministro do Supremo Tribunal Federal.

33 A Relatora especial da ONU para execuções sumárias, Asma Jahangir, no item 82 do relatório da visita que realizou ao Brasil no ano de 2004, apontou que "as unidades do Ministério Público deveriam dispor de um grupo de investigadores e ser encorajadas a realizar investigações independentes contra acusações de execuções sumárias. Obstáculos legais que impedem tais investigações independentes deveriam ser removidos em legislação futura" (Tradução de FURTADO, Valtan. 15 razões para o Ministério Público investigar infrações penais). Na origem: "Public prosecutors' offices should be strengthened. The tenure of the heads of prosecutors' offices should be of a reasonable period, to allow sufficient opportunity to consolidate their work. Prosecutors' offices should be provided with a team of investigators and be encouraged to make independent investigations against charges of extrajudicial executions. Legal obstacles which prevent such independent investigations should be removed through further legislation".

34 MAZZILLI, Hugo Nigro. As investigações do Ministério Público para fins penais. Revista APMP em Reflexão, São Paulo: APMP, a. 1, n. 4, p. 12, 2005 p. 485.

35 No Seminário Internacional "O Papel do Ministério Público na Investigação Criminal", realizado pela Procuradoria-Geral da República e pelo Movimento do Ministério Público Democrático, no dia 12 de março de 2013, expressou-se a preocupação das instituições em relação à retirada dos poderes investigativos na esfera penal do Ministério Público. Íntegra da carta disponível em: <http://www.mp.sp.gov.br/portal/page/ portal/noticias/publicacao_noticias/2013/marco_2013/Carta\%20de\%20Bras\%C3\%ADlia.pdf>. Acesso em: 29 mar. 2013. 
pios do direito internacional, e o Brasil ficaria isolado em relação aos demais 120 países signatários do Estatuto.

Referida carta traz mais um desdobramento negativo da PEC 37/2011 no cenário internacional. Por todo o exposto, não restam dúvidas que o Ministério Público, por suas atribuições conferidas no Texto Constitucional, é um órgão capaz de promover uma investigação preliminar para apuração de infrações criminais, ainda que de forma excepcional ou subsidiária à polícia judiciária, mantendo-se a ordem e a paz social, pressupostos indispensáveis à manutenção de qualquer Estado Democrático de Direito.

\section{CONCLUSÃO}

Pode-se extrair da Constituição de 1988, como responsável por delinear e instituir a ideia de um Estado Democrático de Direito no Brasil, a correta compreensão das competências conferidas aos órgãos encarregados de sua defesa, a partir de um modelo de atividades destinado a apuração de infrações criminais baseado no juízo de cooperação e interferências entre as instituições repressoras do crime - Ministério Público e Polícia Judiciária, as quais estão direcionadas a persecução de um fim comum: a pacificação social.

Destarte, o Ministério Público, mais que um órgão acusador, exsurge como uma instituição vocacionada à defesa da sociedade e do Estado Democrático de Direito, incumbida de elevadas razões jurídicas que evidenciam sua legitimidade investigatória (art. 129, I e IX, da CRFB, c/C arts. 8으, V, da LC 75/1993, 26, da Lei no 8.625/1993, e 4º , parágrafo único, do CPP) na seara criminal, de modo que não há justificativas plausíveis capazes de negar-lhe esse poder.

Com efeito, referidos dispositivos constitucionais, aplicados a uma teoria compatível com o nosso espaço-tempo, inegavelmente, asseguram a possibilidade, ainda que em hipóteses justificadas e considerando o aspecto da "necessidade circunstancial", de investigações criminais realizadas pelo Ministério Público, desempenhadas de forma transparente e à luz da razão pública.

Afinal, restou demonstrado que a Carta Maior não confere monopólio algum da atividade investigatória criminal à Polícia Judiciária, estabelecendo apenas que cabe à autoridade policial a exclusividade sobre o inquérito policial. Contudo, esse instrumento não se afigura como o único meio de investigação entre as diversas formas possíveis de desempenhar essa atividade no contexto da normativa constitucional vigente.

Nesse viés, sendo o Ministério Público, autorizado pela Constituição Federal a conduzir investigações no âmbito criminal, mostra-se totalmente 
incompatível com a realidade brasileira, sobretudo pelo excelente trabalho desempenhado pelo órgão ministerial no combate à impunidade e ao crime organizado, a implantação da Emenda Constitucional no 37/2011, haja vista que tal aprovação acarretaria em uma mudança substancial no sistema processual penal adotado pelo nosso País. Parece-nos, portanto, cada vez mais evidente que eventual decisão contrária a esse entendimento importaria em gravíssimo retrocesso social.

\section{REFERÊNCIAS}

AMADO, Verônica Lazar. A investigação criminal pelo Ministério Público. Aracaju: Gráfica Textopronto, 2002.

BRASIL. Constituição da República Federativa do Brasil: promulgada em 5 de outubro de 1988. Disponível em: <http://www.planalto.gov.br/ccivil_03/constituicao/constituicao.htm>. Acesso em: 18 dez. 2012.

CALABRICH, Bruno F. de C. A investigação criminal pelo Ministério Público: fundamentos e limites constitucionais. Dissertação de Mestrado pela Faculdade Direito de Vitória. Vitória/ES, 2006. Disponível em: <http://www.fdv.br/mestrado/dissertacoes/ Bruno\%20Freire\%20de\%20Carvalho\%20Calabrich.pdf>. Acesso em: 15 mar. 2013.

CARNEIRO, Paulo Cezar Pinheiro. O Ministério Público no processo civil e penal: promotor natural: atribuição e conflito. 5. ed. Rio de Janeiro: Forense, 1995.

CLEVE, Clemerson Merlin. Investigacão criminal e Ministério Público. Disponível em: <http://www.direitodoestado.com/revista/REDE-1-JANEIRO-2005-CLEMERSON\%20 CLEVE.pdf>. Acesso em: 11 dez. 2012.

D'ALMEIDA, Paulo. Matéria da Adepol do Brasil denominada "A hora da verdade", defendendo a PEC 37/2011. Jornal O Estadão de S. Paulo, 15 de janeiro de 2013. Disponível em: <http://www.adepoldobrasil.com.br/2.0/presidente-da-associacao-de-delegados-de-policia-do-brasil-paulo-dalme ida-o-estado-de-s-paulo/>. Acesso em: 10 fev. 2013.

FURTADO, Valtan. 15 razões para o Ministério Público investigar infrações penais. Boletim IBCCrim, a. 45, n. 139, jun. 2004.

LACERDA, Alexandre M. B. Considerações sobre a PEC 37/2011 e seus reflexos na investigação criminal no Brasil. Disponível em: <http://www.conamp.org.br/Lists/artigos/ DispForm.aspx?ID=194>. Acesso em: 9 fev. 2013.

MAZZILLI, Hugo Nigro. As investigações do Ministério Público para fins penais. Revista APMP em Reflexão, São Paulo: APMP, a. 1, n. 4, p. 12, 2005.

. Regime jurídico do Ministério Público. São Paulo: Saraiva, 2007.

PRADO, Geraldo. Sistema acusatório - A conformidade constitucional das leis processuais penais. Rio de Janeiro: Lumen Juris, 2006.

RANGEL, Paulo. Direito processual penal. 18. ed. Rio de Janeiro: Lumes Juris, 2011.

STRECK, Lenio L.; FELDENS, Luciano. Crime e constituição: a legitimidade da função investigatória do Ministério Público. Rio de Janeiro: Forense, 2003. 